\title{
Analisis Gaya Kepemimpinan di Organisasi Pemerintah Daerah (Studi Kasus Kabupaten Merangin)
}

\section{Dedi Epriadi' ${ }^{1}$ Karol Teovani Lodan ${ }^{2}$ Bobby Mandala Putra ${ }^{3}$}

1Program Studi Administrasi Negara, Universitas Putera Batam, Kepulauan Riau.

E-mail: dedi.epriadi@puterabatam.ac.id

2Program Studi Administrasi Negara, Universitas Putera Batam, Kepulauan Riau.

E-mail: karol@puterabatam.ac.id

3Program Studi Administrasi Negara, Universitas Putera Batam, Kepulauan Riau.

E-mail: bobby@puterabatam.ac.id

\section{ARTICLE INFO}

Keywords: Leadership Style, Employee

Performance, Good

Governance

Kata kunci: Gaya

Kepemimipinan,

Kinerja Pegawai, Good

Governance

\section{How to Cite:}

Epriadi, D., Lodan, K.

T., \& Putra, B. M.

(2019). Analisis Gaya

Kepemimpinan di

Organisasi Pemerintah

Daerah (Studi Kasus

Kabupaten Merangin).

JAKPP (Jurnal Analisis

Kebijakan dan Pelayanan

Publik), 49-61.

\section{ABSTRACT}

This research is carried out by a number of problems: how a leader cannot motivate officials to make a job part of what must be governed, in making decisions not carried out properly, incomplete in supporting tasks in accordance with predetermined tasks and functions. Samples in this study were published by 17 people working in the Regional Secretariat of Merangin District, using descriptive survey techniques to study the Analysis of Leadership Styles in Local Government Organizations. The Head of Merangin's Regency Regional Secretariat General's Head was still not optimal in improving employee performance. This is evident from the various discussions relating to the implementation of leadership given: leader's intervention in work, attention of leaders in providing input to complete tasks, praising and criticizing leadership for subordinate support and listening to any opinions and suggestions given by subordinates. Barriers issued by the Head of the General Section of the Merangin Regency Regional Secretariat include: leadership and human resource work competence. To overcome the difficulties issued by the Head of the General Section of the Merangin Regency Regional Secretariat, they have made various efforts, discussing: increasing the competency of coaching employees and increasing the managerial ability of human resources from leadership.

\footnotetext{
Abstrak

Penelitian ini dilakukan oleh beberapa masalah diantaranya : bagaimana seorang pimpinan kurang bisa memotivasi para pegawai untuk menjadikan suatu pekerjaan bagian dari dirinya tanpa harus diperintah, dalam pengambilan keputusan tidak terlaksana dengan semestinya, kurang merata nya dalam pemberian tugas yang berdasarkan tupoksi yang telah ditetapkan. Sampel dalam penelitian ini berjumlah 17 Orang yang bekerja pada Bagian Setda Kabupaten Merangin, menggunakan teknik Survey dengan deskriptif bertujuan mengetahui Analisis Gaya Kepemimpinan di Organisasi Pemerintah Daerah. Kepimimpian Kepala Bagian Umum Sekretariat Daerah Kabupaten Merangin masih belum optimal dalam meningkatkan kinerja pegawai. Hal ini tampak dari berbagai permasalahan yang terkait dengan pelaksanaan kepemimpinan yang meliputi: campur tangan pimpinan dalam pekerjaan, perhatian pimpinan dalam memberikan masukan untuk penyelesaian tugas, pujian dan kritik pimpinan atas kinerja bawahan dan mendengarkan setiap pendapat dan saran yang diberikan bawahan. Hambatan yang dihadapi oleh Kepala Bagian Umum Sekretariat Daerah Kabupaten Merangin dalam kepemimpinan meliputi: kurangnya kesadaran dan disiplin kerja pegawai dan kurangnya kemampuan pimpinan dalam manajemen sumber daya manusia. Untuk mengatasi hambatan yang dihadapi oleh Kepala Bagian Umum Sekretariat Daerah Kabupaten Merangin telah dilakukan berbagai upaya
} 
diantaranya adalah: meningkatkan intensitas pembinaan pegawai dan meningkatkan

kemampuan manajerial sumber daya manusia dari pimpinan.

Copyright @ 2017 JAKPP. All rights reserved.

\section{Pendahuluan}

Pemerintahan dibentuk dengan maksud untuk membangun peradaban dan menjaga sistem ketertiban sosial sehingga masyarakat bisa menjalani kehidupan secara wajar dalam konteks kehidupan berbangsa dan bernegara. Dalam perkembangannya, konsep pemerintahan telah mengalami transformasi paradigma dari yang serba negara ke orientasi pasar (market or public interest), dari pemerintahan yang kuat, besar dan otoritarian ke orientasi (small and less government), egalitarian dan demokratis, serta transformasi kepada sistem pemerintahan dari yang sentralistik ke desentralistik.

Penyelenggaraan roda pemerintahan yang baik dan bersih adalah landasan bagi penyusunan dan penerapan kebijakan suatu negara yang demokratis dalam era globalisasi saat ini. Fenomena demokrasi ditandai dengan menguatnya kontrol masyarakat terhadap penyelenggaraan pemerintahan, sementara fenomena globalisasi ditandai dengan saling ketergantungan antara bangsa, terutama dalam pengelolaan sumber-sumber daya ekonomi dan aktivitas dunia usaha.

Sehubungan dengan itu, sebuah konsep baru yang semula diperkenalkan lembagalembaga donor internasional, yaitu konsep tata kepemerintahan yang baik (good governance), sekarang menjadi salah satu kata kunci dalam wacana untuk membenahi sistem penyelenggaraan pemerintahan di Indonesia. Upaya untuk mewujudkan good local governance bukanlah suatu hal yang sangat mudah seperti membalik telapak tangan dan tentunya untuk mewujudkan itu semua dibutuhkan perjuangan dan waktu cukup panjang. Sekalipun memiliki kelemahan, penyelengaraan desentralisasi merupakan sarana yang mendekatkan Bangsa Indonesia pada kondisi yang ideal untuk membangun good local governance.

Kepemimpinan mempunyai peranan penting dan sentral dalam kehidupan organisasi maupun berkelompok. Untuk mencapai tujuan bersama, manusia di dalam organisasi perlu membina kebersamaan dengan mengikuti pengendalian dari pemimpinnya. Dengan pengendalian tersebut, perbedaan keinginan, kehendak, kemauan, perasaan, kebutuhan dan lain-lain dipertemukan untuk digerakkan kearah yang sama. Dengan demikian berarti di dalam setiap organisasi perbedaan individual dimanfaatkan untuk mencapai tujuan yang sama sebagai kegiatan kepemimpinan.

Pada sisi lain, organisasi dapat pula terbentuk karena kesamaan sejumlah individu atau merasa memiliki kepentingan yang sama pula. Dengan berhimpun di dalam suatu kelompok, kesamaan dan kepentingan yang sama itu akan lebih mudah diwujudkan dibandingkan jika perwujudannya dilakukan secara individual (perseorangan). Di dalam kelompok itu muncul seorang atau lebih pemimpin karena memiliki kelebihan berupa kemampuan kepemimpinan. Kelompok seperti itu menyusun sendiri posisi jabatan kepemimpinan di lingkungannya sesuai keperluan dan kondisi masing-masing.

Seorang pemimpin sebagai individu merupakan suatu kepribadian yang berhadapan dengan sejumlah individu lainnya yang masing-masing juga merupakan suatu kepribadian. Dalam keadaan seperti itu seorang pemimpin harus memahami setiap kepribadian yang 
berbeda dengan kepribadiannya sendiri. Pemimpin sebagai suatu kepribadian memiliki motivasi yang mungkin tidak sama dengan motivasi anggota kelompoknya, baik dalam mewujudkan kehendak untuk bergabung dan bersatu dalam suatu kelompok maupun dalam melaksanakan kegiatan yang menjadi tugas dan tanggung jawab masing-masing.

Dalam suatu organisasi pemerintah, setiap pemimpin merupakan pribadi sentral yang sangat besar pengaruhnya terhadap pegawainya yang terlihat dalam sikap dan perilakunya pada waktu melaksanakan tugas dan tanggung jawabnya. Khususnya pada Bagian Umum Setda Kabupaten Merangin, terutama yang berkaitan dengan peningkatan kinerja pegawai dalam melaksanakan pekerjaannya. Kinerja pegawai merupakan hasil kerja yang dapat dicapai seseorang atau sekelompok orang dalam suatu organisasi sesuai wewenang dan tanggung jawab masing-masing dalam rangka mewujudkan tujuan organisasi.

Gaya kepemimpinan yang efektif dibutuhkan dalam meningkatkan kinerja semua pegawai dalam mencapai tujuan organisasi sebagai instansi pelayanan publik. Permasalahan yang sering dialami oleh Bagian Umum Setda Kabupaten Merangin diamati penulis adalah menyangkut bagaimana seorang pimpinan kurang bisa memotivasi para pegawai untuk memahami dan menjadikan suatu pekerjaan bagian dari dirinya dan melakukannya tanpa harus diperintah serta dalam pengambilan keputusan tidak terlaksana dengan semestinya, kurang merata nya dalam pemberian tugas yang berdasarkan tupoksi yang telah ditetapkan. Sebagian pegawai tidak mempunyai kinerja yang tepat pada bidang nya, dan kurang terlaksananya rapat koordinasi secara rutin dan terprogram oleh pimpinan, sehingga menyulitkan untuk mengukur kinerja dari setiap pegawai di Bagian Umum Setda Kabupaten Merangin.

Secara khusus, pada saat penulis melakukan pra penelitian, permasalahan pada Kepemimpinan Dalam Meningkatkan Kinerja Pegawai Menuju Good Governance pada Bagian Sekretaris Daerah Kabupaten Merangin ditemukan beberapa fenomena diantaranya :

1. Pimpinan kurang bisa memotivasi para pegawai untuk memahami dan menjadikan suatu pekerjaan bagian dari dirinya dan melakukannya tanpa harus diperintah serta dalam pengambilan keputusan tidak terlaksana dengan semestinya.

2. Kurang merata nya dalam pemberian tugas yang berdasarkan tugas pokok dan fungsi yang telah ditetapkan.

3. Sebagian pegawai tidak mempunyai kinerja yang tepat pada bidang nya.

4. Kurang terlaksananya rapat koordinasi secara rutin dan terprogram oleh pimpinan.

Bagaimana Gaya Kepemimpinan di Organisasi Pemerintah Daerah : Studi Kasus Kabupaten Merangin?

\section{Kajian Literatur}

Analisis adalah cara mengkaji dengan lebih mendalam terhadap sesuatu masalah, serta menguraikan bagian-bagian atau komponen dari yang dianalisis. Menurut WJS. Poerwadarminta (1998:16) dimaksud dengan analisis adalah penyelidikan suatu peristiwa untuk mengetahui apa sebab-sebabnya, bagaimana duduk perkara atau persoalan yang sebenarnya.

Disamping itu menurut Komaruddin (1994:311) Analisis adalah kegiatan berpikir untuk menguraikan suatu keseluruhan menjadi komponen-komponen 
sehingga dapat mengenal tanda-tanda komponen-komponen hubungannya satu sama lain dan fungsi masing-masing dalam suatu keseluruhan yang terpadu.

Jadi dapat ditarik kesimpulan bahwa analisis merupakan kegiatan penyidikan suatu peristiwa dengan tujuan untuk mengetahui kebenaran dari peristiwa tersebut dengan mengetahui hubungannya satu sama lain dan fungsi dari keseluruhan peristiwa tersebut dengan cara penyelidikan suatu peristiwa untuk mengetahui apa sebab-sebabnya, bagaimana duduk perkara atau persoalan yang sebenarnya.

Menurut Alijoyo (2004:92) governance dalam arti sempit pada dasarnya berbicara tentang dua aspek yakni, governance structure atau board structure dan governance process atau governance mechanism pada suatu perusahaan. Governance structure adalah struktur hubungan pertanggungjawaban dan pembagian peran diantara berbagai organ utama perusahaan yakni Pemilik/Pemegang Saham, Pengawas/ Komisaris, dan Pengelola/Direksi/Manajemen. Sedangkan governance process membicarakan tentang mekanisme kerja dan interaksi aktual di antara organorgan tersebut. Meskipun pada dasarnya governance process dipengaruhi oleh governance structure, mekanisme kerja dan interaksi aktual diantara organ-organ korporasi dapat berjalan menyimpang dari struktur yang ada.

Dengan demikian tata pemerintahan adalah penggunaan wewenang ekonomi politik dan administrasi guna mengelola urusan-urusan Negara pada semua tingkat. Tata pemerintahan mencakup seluruh mekanisme, proses dan lembaga-lembaga dimana warga dan kelompok-kelompok masyarakat mengutarakan kepentingan mereka, menggunakan hak hukum, memenuhi kewajiban dan menjembatani perbedaan-perbedaan diantara mereka. Karakteristik good governance adalah masyarakat sipil yang kuat dan partisipatoris, terbuka, pembuatan kebijakan yang dapat diprediksi, eksekutif yang bertanggung jawab, birokrasi yang profesional dan aturan hukum.

Amrizal (2015:37) Strategi Pimpinan pada Badan Pengelolaan Keuangan dan Aset Daerah Kabupaten Bungo sudah melaksanakan tugas, pokok dan fungsi secara umum, khususnya dalam menerapkan Good Governance. Upaya yang telah dilakukan adalah dalam bentuk Memahami karakteristik para staf (bawahannya) sehingga dapat melakukan pendekatan, memotivasi, mempengaruhi dan mengarahkan staf atau bawahannya dengan teknis yang sesuai. Badan Pengelolaan Keuangan dan Aset Daerah adalah Koordinasi bagi Satuan Kerja Perangkat Daerah (SKPD) lain dalam bidang keuangan, melakukan pembinaan, penempatan Pegawai sesuai dengan keahlian dan latar belakang pendidikannya, penganggakatan Pejabat Eselon berdasarkan pengalaman dan kemampuan, pemberian hadiah kepada pegawai yang berprestasi, permberian hadiah bagian pegawai yang berprestasi, pengaraharan Sistem Informasi dalam rangka Pengelolaan Keuangan Daerah dan pemberian Pelatihan kepada pegawai. Hambatan yang dihadapi oleh Pimpinan dalam Menerapkan Good Governance pada Badan Pengelolaan Keuangan dan Aset Daerah Kabupaten Bungo diantaranya, Masih terdapatnya Satuan Kerja Perangkat Daerah (SKPD) dalam proses penganggaran yang tidak sesuai dengan tahapan-tahapan perencanaan serta belum konsistennya penganggaran yang disesuaikan dengan 
program dan kegiatan, masih kurangnya kemampuan Sumber Daya Manusia, kurangnya kedisiplinan pegawai dalam bekerja. Upaya mengatasi hambatan yang dihadapi Pimpinan dalam menerapkan Good Governance pada Badan Pengelolaan Keuangan dan Aset Daerah Kabupaten Bungo adalah dengan melakukan, menentukan anggaran sesuai dengan program dan kegiatan yang akan dilaksanakan, Meningkatkan Kualitas Sumber Daya Manusia dan Menegakkan kedisplinan pada pegawai

\section{Metode Penelitian}

Penelitian ini merupakan jenis penelitian kualitatif. Menurut Strauss dan Corbin (2003) dalam Afrizal (2015) Penelitian kualitatif didefinisikan sebagai jenis penelitian yang temuan-temuannya tidak diperoleh melalui prosedur statistik atau bentuk hitungan lainnya.

Dalam penelitian ini peneliti menggunakan teknik Wawancara dengan deskriptif. Mengambil lokasi yang bertempat di Bagian Umum Sekretaris Daerah Kabupaten Merangin Provinsi Jambi dengan jumlah sampel sebanyak 17 Orang yang dianggap memahami informasi terkait permasalahan. Dalam pelaksanaan penelitian yang dilakukan menggunakan beberapa teknik pengumpulan data antara lain dengan Observasi dan Wawancara.

Metode analisis data yang di gunakan dalam penelitian ini adalah model Miles dan Huberman, dengan langkah dan tahapan Reduksi Data, Penyajian Data, dan Conclusion Drawing.

\section{Hasil dan Pembahasan}

\section{Gaya Kepemimpinan Dalam Meningkatkan Kinerja Pegawai}

Keberhasilan dalam pelaksanaan tugas Pemerintah Daerah tidak lepas dari Satuan Kerja Perangkat Daerah (SKPD) yang menjalankan visi dan misi Pemerintah Daerah. Bagian Umum merupakan salah satu unit kerja Sekretariat Daerah Kabupaten Merangin Provinsi Jambi, yang bertanggungjawab langsung dalam Perumusan Kebijakan dan Penyelenggaraan Pelayanan Administrasi Umum, Perlengkapan dan Rumah Tangga, Keprotokolan dan Sandi Telekomunikasi di lingkungan Sekretariat Daerah Kabupaten Merangin Provinsi Jambi. Untuk meningkatkan kinerja Bagian Umum Setda Kabupaten Merangin salah satunya ditentukan oleh kepemimpinan Kepala Bagian Umum dalam membina dan memotivasi bawahannya. Gaya kepemimpinan menggambarkan prilaku pemimpin kepada bawahannya. Berdasarkan hasil wawancara dengan salah satu pegawai yang menyatakan bahwa Kabag Umum selalu lebih cenderung untuk bertingkah laku secara demokratik dan mengambil bagian dimana mereka lebih menghormati dan prihatin terhadap bawahanny. 
“......Kabag Umum selalu lebih cenderung untuk bertingkah laku secara demokratik dan mengambil bagian dimana mereka lebih menghormati dan prihatin terhadap bawahanny".

Berdasarkan hasil wawancara dengan salah seorang pegawai yang menyatakan bahwa ditemukan paling banyak yang dilakukan kepala bagian yang menggambarkan sikap demokratis adalah jika pegawai pelaksana mengalami masalah pekerjaan, tindakan yang dilakukan adalah berdiskusi bersama dengan pegawai yang lain.

“.......Paling banyak yang dilakukan kepala bagian yang menggambarkan sikap demokratis adalah jika pegawai pelaksana mengalami masalah pekerjaan, tindakan yang dilakukan adalah berdiskusi bersama dengan pegawai yang lain".

Dari hasil wawancara di atas dapat di simpulkan bahwa Gaya kepemimpinan demokrasi dengan semangat kerja yang tinggi, dimungkinkan sikap dari Kepala Bagian Umum yang mau bekerja sama dengan pegawai, sehingga pegawai merasa dihargai dalam bekerja. Berhubungan dengan faktor - faktor yang mengakibatkan semangat kerja adalah hubungan yang harmonis antara pimpinan dengan bawahan terutama antara pimpinan kerja sehari-hari langsung berhubungan dan berhadapan dengan para bawahan, Rasa pemanfaatan bagi tercapainya tujuan organisasi yang juga merupakan tujuan bersama mereka yang harus diwujudkan secara bersamasama.

Untuk melihat lebih jauh sejauh mana gaya kepemimpinan Kabag Umum Setda Kabupaten Merangin dalam meningkatkan kinerja pegawai, maka dapat dijelaskan melalui uraian di bawah ini.

\section{Analisis Terhadap Campur Tangan Pimpinan dalam Pekerjaan.}

Kabag Umum Setda Kabupaten Merangin dalam memimpin bawahannya memperhatikan pelaksanaan tugas bawahannya. Berdasarkan hasil wawancara dengan pegawai yang menyatakan bahwa Kabag Umum memberikan arahan dan masukan terhadap pegawai terkait dengan tugas yang diberikan kepada bawahannya. Dengan kata lain, Kabag Umum memberikan arahan dan masukan terhadap tugas yang diberikan kepada bawahan, dimana dalam setiap pemberian tugas selalu memberikan petunjuk, arahan kepada bawahan sehingga bawahan dapat memahami pekerjaan yang akan dilakukan.

“......Kabag Umum memberikan arahan dan masukan terhadap pegawai terkait dengan tugas yang diberikan kepada bawahannya, memberikan arahan dan masukan terhadap tugas yang diberikan kepada bawahan, serta selalu memberikan petunjuk, arahan kepada bawahan sehingga bawahan dapat memahami pekerjaan yang akan dilakukan".

Berdasarkan hasil wawancara dengan pegawai bagian umum, yang menyatakan bahwa Kabag Umum relatif terlalu ikut campur tangan terhadap 
pekerjaan dan tugas dari bawahan. Hal ini juga dikatakan oleh Kasubag Perlengkapan dan rumah tangga bahwa Kabag Umum terlalu berlebihan dalam memberikan petunjuk dan campur tangan hampir kepada setiap tugas yang diberikan kepada bawahan.

“.... Kurangnya kepercayaan terhadap bawahan sehingga relatif terlalu ikut campur tangan terhadap pekerjaan dan tugas yang dilakukan oleh bawahanbawahan. Dengan terlalu berlebihan dalam memberikan petunjuk dan campur tangan hampir kepada setiap tugas yang diberikan kepada bawahan berakibat bawahan merasa tidak diberikan kepercayaan terhadap tugas yang telah diberikan oleh pimpinan".

Berdasarkan pengamatan dan wawancara peneliti, dapat disimpulkan bahwa kepemimpinan Kabag Umum dalam menangani tugas bawahan relatif berlebihan, dimana pimpinan terlalu campur tangan terhadap tugas yang seharusnya dipercayakan kepada bawahan dan berakibat bawahan merasa tidak diberikan kepercayaan terhadap tugas yang telah diberikan oleh pimpinan.

\section{Analisis Perhatian Pimpinan dalam Memberikan Masukan untuk Penyelesaian Tugas}

Untuk mengetahui kepemimpinan Kabag. Umum terhadap perhatian yang diberikan kepada bawahan, maka dari hasil wawancara dengan sebagian pegawai, bahwa pimpinan sudah cukup memperhatikan bawahan dalam memberikan masukan untuk penyelesaian tugas bawahan. Hal yang sama juga dikatakan oleh Kasubag Protokol dan Santelda, bahwa perhatian dalam memberikan masukan kepada bawahan sudah bersifat membimbing dalam pelaksanaan tugas secara terperinci.

Berdasarkan dari hasil wawancara dengan beberapa pegawai lainnya yang menyatakan, bahwa Kabag. Umum masih pilih kasih dalam memberikan masukan kepada bawahan, dimana tidak semua pegawai menerima perhatian dan masukan dalam pelaksanaan tugas masing-masing.

“......Dalam pemberian masukan kepada bawahan, pimpinan masih pilih, dimana tidak semua pegawai menerima perhatian dan masukan dalam pelaksanaan tugas masing-masing".

Dari berbagai wawancara di atas, maka tergambar kepemimpinan Kabag. Umum dalam memberikan masukan dan perhatian sehubungan dengan penyelesaian tugas bawahan, walaupun dirasakan oleh sebagian pegawai terhadap ketidakadilan yang diberikan oleh atasan. 


\section{Analisis Pujian dan Kritik Pimpinan atas Kinerja Bawahan}

Kabag Umum dalam melakukan pembinaan dan motivasi kepada bawahan relatif kurang, dimana setiap hasil kerja dari bawahan jarang diberikan komentar, apakah baik atau belum. Hal ini disebabkan oleh pemimpin yang terlalu ikut campur dan relatif terlibat terhadap semua pekerjaan dari bawahan.

Berdasarkan wawancara dengan salah seorang pegawai, bahwa Kabag Umum kurang aktif dalam memberikan kritikan maupun pujian terhadap hasil kinerja bawahan. Hal ini juga didukung oleh Kasubbag Perlengkapan dan Rumah Tangga, bahwa Kabag Umum kurang memperhatikan dampak psikologis terhadap pujian dan kritikan kepada bawahan terkait dengan hasil kerja bawahannya.

“.....Kurang aktif dalam memberikan kritikan maupun pujian terhadap hasil kinerja bawahan, kurang memperhatikan dampak psikologis terhadap pujian dan kritikan kepada bawahan terkait dengan hasil kerja bawahannya sehingga rendahnya semangat bawahan dalam menyelesaikan tugasnya".

Penerapan disiplin PNS secara umum sudah mengatur terhadap pemberian reward dan punishmen kepada pegawai negeri. Namun berdasarkan pengamatan peneliti, sebagian besar pelaksanaan disiplin PNS belum berjalan di Bagian Umum Sekda Kabupaten Merangin. Begitu juga aturan promosi yang dirasakan juga belum objektif terhadap pegawai yang berprestasi. Promosi bukan hanya penting untuk pegawai saja, melainkan juga penting bagi instansi itu sendiri, karena programprogram promosi merupakan pencerminan supaya instansi untuk mempertahankan sumber daya manusianya.

\section{Analisis Pimpinan Mendengarkan Setiap Pendapat dan Saran yang Diberikan Bawahan}

Salah satu ciri-ciri pemimpin yang bijaksana adalah dalam menerima saran dan pendapat dari bawahan terhadap kemajuan organisasi serta menentukan tujuan organisasi, memotivasi perilaku pengikut untuk mencapai tujuan, serta mempengaruhi untuk memperbaiki kelompok dan budayanya. Namun dalam praktek jarang ditemukan pimpinan yang mau menerima saran dan kritikan yang disebabkan oleh adanya arogan pimpinan.

Berdasarkan wawancara dengan salah seorang pegawai, bahwa Kabag Umum relatif kurang dalam menanggapi pendapat dan masukan dari bawahan. Hal ini juga didukung oleh pegawai lainnya, bahwa setiap saran dan kritikan yang diberikan selalu kurang ditanggapi oleh Kabag. Umum, sehingga sebagian bawahan enggan untuk memberikan kritikan dan masukan untuk perbaikan kinerja bagian umum.

“.......Kabag umum masih kurang dalam menanggapi pendapat dan masukan dari bawahan, terbukti dengan saran dan kritikan yang diberikan selalu kurang ditanggapi, segingga mengakibatkan bawahan enggan untuk 
memberikan kritikan dan masukan untuk perbaikan kinerja bagian umum. Pemimpinan yang baik dan benar ini sangat diperlukan oleh bawahan sabagai panutan untuk menjadi orang yang sukses dan dapat menerapkan perilaku pemimpin yang baik ketika mereka dapat menjadi posisi sebagai pemimpin".

Berdasarkan wawancara di atas, peneliti menyimpulkan bahwa Kabag Umum kurang merespon terhadap saran dan pendapat yang disampaikan oleh bawahan untuk peningkatan kinerja organisasi Bagian Umum Setda Kabupaten Merangin.

\section{Diskusi}

\section{Hambatan Kepemimpinan dalam Meningkatkan Kinerja Pegawai}

Adapun hambatan Kepemimpinan dalam meningkatkan kinerja pegawai sebagai berikut:

\section{Kurangnya Kesadaran dan Disiplin Kerja Pegawai}

Menurut Sastrohadirwiryo (2002:291) Mengemukakan bahwa disiplin kerja adalah sebagai sikap menghormati, menghargai, patuh dan taat terhadap peraturan-peraturan yang berlaku, baik yang tertulis maupun tidak tertulis serta sanggup menjalankan dan tidak mengelak untuk menerima sanksi-sanksinya apabila melanggar tugas dan wewenang yang diberikan kepadanya.

Hambatan utama yang dihadapi oleh Bagian Umum Setretaris Daerah Kabupaten Merangin dalam meningkatkan kinerja pegawai untuk melakukan pelayanan administrasi disebabkan oleh kurangnya kesadaran dan disiplin kerja dari sebagian pegawai dalam pelayanan administrasi.

“......Sumber daya manusia pada hakekatnya merupakan salah satu modal dan memegang peranan yang sangat penting dalam keberhasilan organisasi. Kurangnya kesadaran dan kedisiplinan para pegawai menjadikan para pegawai dihadapkan pada masalah yang berakibat pada menurunnya kinerja".

Dari pengamatan peneliti terlihat bahwa sebagian pegawai belum memiliki disiplin kerja yang diharapkan, seperti dalam pelaksanaan Tupoksi masing-masing dan disiplin terhadap jam kerja yang telah ditentukan. Hal ini juga dikatakan oleh Kasubbag TU, bahwa masih ada sebagian pegawai hanya melaksanakan tugas rutin dari sisi kehadiran apel pagi dan apel sore.

Dengan kondisi yang dipaparkan di atas, menyebabkan peranan pemimpin dalam meningkatkan kinerja pegawai dalam pelayanan administrasi masih belum optimal untuk mendukung kinerja pelayanan administrasi di lingkungan Setda Kabupaten Merangin. 


\section{Masih Kurangnya Kemampuan Pimpinan Dalam Memotivasi Kinerja Bawahan}

Dalam upaya meningkatkan kinerja pegawai dalam melakukan pelayanan administrasi terhambat oleh belum optimalnya pemimpin dalam melakukan pembinaan dan motivasi kepada bawahan. Hal ini juga disebabkan oleh kurangnya pengetahuan dan keterampilan Kabag Umum dalam menerapkan strategi manajemen sumber daya manusia. Pegawai merupakan makluk social dengan berbagai karakter dan latar belakang yang berbeda-beda, sehingga perlu perlakuan yang berbeda juga dalam memotivasi semangat kerjanya.

Berdasarkan wawancara dengan Kasubag TU dan Kearsipan, bahwa:

“.....Keterbatasan penerapan manajemen sumber daya manusia oleh Kabag Umum sangat mempengaruhi semangat kerja pegawai dalam meningkatkan kualitas pelayanan administrasi umum sesuai dengan standar yang telah ditetapkan".

Berdasarkan wawancara di atas, dapat diidentifikasikan bahwa salah satu hambatan dalam pelaksanaan kinerja pelayanan administrasi umum pada Setda Kabupaten Merangin disebabkan oleh keterbatasan kemampuan manajerial sumber daya manusia dari Kabag Umum.

\section{Upaya Mengatasi Hambatan Kepemimpinan dalam Meningkatkan Kinerja Pegawai}

Upaya-upaya yang dilakukan oleh Bagian Umum Sekretaris Daerah Kabupaten Merangin atas adanya hambatan yang dihadapi, antara lain adalah:

\section{Meningkatkan Intensitas Pembinaan Pegawai}

Upaya yang dilakukan terhadap pegawai yang masih rendah kesadaran dalam melaksanakan tugas pokok dan fungsinya adalah melalui pembinaan oleh atasan, baik secara kolektif maupun antar personal. Pembinaan secara kolektif dilakukan melalui program sosialisasi tentang pokok-pokok aturan kepegawaian. Sedangkan pembinaan secara personal dilakukan dengan pemanggilan terhadap pegawai yang kurang disiplin, baik disiplin jam kerja, maupun disiplin dalam melaksanakan pekerjaan

Berdasarkan wawancara dengan Kabag Umum, yang menyatakan bahwa : 
“....Salah satu upaya yang dilakukan untuk meningkatkan disiplin pegawai adalah melalui penerapan aturan yang tegas kepada semua pegawai dan pemberian sanksi sesuai dengan aturan yang berlakun".

Hal ini juga didukung oleh Kasubag TU dan Kearsipan, bahwa :

“.....Untuk meningkatkan kesadaran pegawai untuk melaksanakan tugas sesuai dengan Tupoksi masing-masing, perlu dilakukan pembinaan secara intensif melalui pendekatan secara pribadi kepada pegawai yang bersangkutan....".

Sedangkan menurut Kasubag Protokol dan Santelda, yang menyatakan bahwa :

“.....Upaya lain disamping melalukan pembinaan kepada pegawai yang bermasalah, perlu juga dilakukan mutasi kebagian lain sebagai bentuk hukuman kepada pegawai yang bersangkutan".

Berdasarkan wawancara di atas, peneliti menyimpulkan perlu adanya usaha pembinaan secara intensif dan terprogram terhadap pegawai di Bagian Umum Setda Kabupaten Merangin. Disamping itu juga perlu adanya roling sebagai bentuk hukuman kepada pegawai yang kurang disiplin.

\section{Meningkatkan Kemampuan Pimpinan dalam Memotivasi Pegawai.}

Salah satu faktor yang paling penting yang harus dimiliki oleh Kabag Umum Setda Kabupaten Merangin adalah keterampilan dalam manajemen sumber daya manusia. Karena keberhasilan dari suatu organiasi tergantung dari kemampuan pimpinan dalam menggerakkan semua bawahan untuk mencapai tujuan yang telah ditetapkan. Apalagi pada sector pemerintahan, akan lebih sulit menerapkan manajemen sumber daya manusia, karena motivasi dan semangat kerja pegawai yang relatif rendah dibandingkan dengan sektor swasta.

".......Salah satu factor penting yang harus dimiliki oleh seorang pemimpin adalah keterampilan dalam manajemen sumber daya manusia. Karena keberhasilan dari sebuah organisasi tergantung dari kemampuan pimpinan dalam menggerakan semua bawahan untuk mencapai tujuan dari sebuah organisasi yang telah ditetapkan".

Untuk itu diharapkan kepada Kabag Umum senantiasa untuk selalu meningkatkan kemampuan manajemen sumber daya manusia, baik melalui pendidikan formal maupun informal. Pendidikan formal dapat dilakukan dengan cara melanjutkan pendidikan kejenjang yang lebih tinggi dibidang manajemen sumber daya manusia. Sedangkan jalur informal dapat dilakukan melalui pelatihan-pelatihan 
kepemimpinan dan manajemen sumber daya manusia yang diadakan oleh berbagai lembaga pelatihan.

\section{Kesimpulan}

Berdasarkan hasil pembahasan atas kepemimpinan Kepala Bagian Umum Sekretaris Daerah Kabupaten Merangin dalam meningkatkan kinerja pegawai seperti yang telah dipaparkan di muka, akhirnya penulis dapat menarik kesimpulan dan mengemukakan pula beberapa saran untuk perbaika.

Kepimimpian Kepala Bagian Umum Sekretariat Daerah Kabupaten Merangin masih belum optimal dalam meningkatkan kinerja pegawai. Hal ini tampak dari berbagai permasalahan yang terkait dengan pelaksanaan kepemimpinan yang meliputi: campur tangan pimpinan dalam pekerjaan, perhatian pimpinan dalam memberikan masukan untuk penyelesaian tugas, pujian dan kritik pimpinan atas kinerja bawahan dan mendengarkan setiap pendapat dan saran yang diberikan bawahan. Hambatan yang dihadapi oleh Kepala Bagian Umum Sekretariat Daerah Kabupaten Merangin dalam kepemimpinan meliputi: kurangnya kesadaran dan disiplin kerja pegawai dan kurangnya kemampuan pimpinan dalam manajemen sumber daya manusia. Untuk mengatasi hambatan yang dihadapi oleh Kepala Bagian Umum Sekretariat Daerah Kabupaten Merangin telah dilakukan berbagai upaya, diantaranya adalah: meningkatkan intensitas pembinaan pegawai dan meningkatkan kemampuan manajerial sumber daya manusia dari pimpinan.

\section{Saran-saran}

Kepada Kepala Bagian Umum Sekretariat Daerah Kabupaten Merangin agar menerapkan penegakan disiplin pegawai dalam melakukan tugas sehari-hari sesuai dengan bidang masing-masing, Agar Kepala Bagian Umum Sekretariat Daerah Kabupaten Merangin menerapkan sistem punish and reward sesuai dengan kinerja pegawai. Kepada Pegawai Bagian Umum Sekretariat Daerah Kabupaten Merangin Agar meningkatkan kesadaran sebagai aparat pemerintah sebagai pelayan masyarakat.

\section{Daftar Pustaka}

Afrizal. (2015). Metode Penelitian Kualitatif: Sebuah Upaya Mendukung Penggunaan. Penelitian Kualitatif dalam Berbagai Disiplin Ilmu. Jakarta: PT Raja.

Alijoyo. (2004). Pelaksanaan Good Corporate Governance, Jakarta : PT. Damar Mulia.

Bintoro Tjokroamidjojo dan Mustofa Adidjoyo. (1995). Teori dan Strategi Pembangunan Nasional, Jakarta : CV. Haji Mas Agung.

Danim, Sudarwan. (2004). Motivasi Kepemimpinan dan Efektivitas Kelompok, Jakarta : PT Rineka Cipta Utama. 
Hadari Nawawi. (2002). Manjemen Strategi, Yogyakarta : Gadjah Mada Pers.

HAW, Widjaja. (2002). Otonomi Daerah,Jakarta : Rajawali Press.

Husaini Usman dan Purnomo Setiadi A. (2003). Metodologi Penelitian Sosial,Bumi Aksara: Jakarta.

Kartini Kartono. (2003). Pemimpin dan Kepemimpinan. apakah kepemimpinan abnormal, Jakarta : PT. Grafindo Persada.

Komaruddin. (1994). Manajemen Public Relations: Konsep dan Aplikasinya, Jakarta : Bumi Aksara.

Mamesah,D.J. (1995).Sistem Administrasi Keuangan Daerah, Jakarta : PT. Gramedia Pustaka Utama.

Rangkuti, Freddy, (2006). Riset Pemasaran,Jakarta : Gramedia.

Sastrohadirwiryo. (2002). Manajemen Tenaga Kerja Indonesia. Pendekatan Administrasi dan Operasional. Jakarta : Bumi Aksara.

Sedarmayanti. (2007). Sumber Daya Manusia dan Produktivitas Kerja, (Bandung : Mandar Maju.

Sugiono. (2000). Metode Penelitian Administrasi, Bandung : Alfabeta.

Winardi. (2000). Kepemimpinan Dalam Manajemen, Jakarta : PT. Rieneka Cipta.

W,J.S. Poerwadarminta (1998). Metodologi Penelitian, Jakarta : Bumi Aksara. 